\title{
Adipose Tissue Metabolism and Production Responses to Calcium Propionate and Chromium Propionate*
}

\author{
J. P. McNamara ${ }^{1}$ and F. Valdez ${ }^{2}$ \\ ${ }^{1}$ Department of Animal Sciences, Washington State University, Pullman 99164-6351 \\ ${ }^{2}$ Kemin Agri Foods North America, Inc., Des Moines, IA 50301
}

\begin{abstract}
The objective was to determine action of calcium propionate and chromium propionate on lipogenesis and lipolysis in adipose tissue, dry matter (DM) intake, milk production and composition, and serum glucose and free fatty acids in Holstein dairy cattle treated from $21 \mathrm{~d}$ prepartum to $35 \mathrm{~d}$ postpartum. Twelve multiparous animals were assigned to each treatment: control (C), calcium propionate (CaP, $0.125 \mathrm{~kg} / \mathrm{d})$, chromium propionate (CrP, $10 \mathrm{mg}$ of trivalent $\mathrm{Cr} / \mathrm{d}$ ), and both. All animals were switched to control at 36 days in milk (DIM) and the trial continued to 90 DIM. Biopsies of adipose tissue were taken at $-7,14,28$, and $56 \mathrm{~d}$ from calving. Control intake prepartum was $10.6 \pm 2 \mathrm{~kg} / \mathrm{d}$. Calcium propionate increased DM intake $11 \%$ prepartum and $13 \%$ postpartum; CrP increased DM intake 7 and 16\%; and the combination treatment had no effect. Milk yield was $44.2 \mathrm{~kg} /$ $\mathrm{d}$ for controls and $46.8 \mathrm{~kg} / \mathrm{d}$ for d 1 to 90 for CrP-treated cows. Adipose tissue lipogenesis in cows treated with either $\mathrm{CaP}$ or $\mathrm{CrP}$ was 1.25 to 78 times as fast as controls from 14 to $56 \mathrm{~d}$ and had returned to prepartum rates by 56 d. From 14 to 28 d, basal lipolysis in CaP- or CrPtreated cows ranged from 27 to $102 \%$ of control, whereas stimulated lipolysis was 61 to $113 \%$ of control. Milk fat yield was 92 to $95 \%$ of control on calcium and chromium propionate; the difference was similar to the net reduction in adipose lipolysis. Milk lactose, protein, and solidsnot-fat did not differ among treatments. Providing a small amount of gluconeogenic precursors may reduce net lipolysis, allowing increased feed intake and milk production. The effect is thought to be through chromium acting to increase glucose flux into adipocytes.
\end{abstract}

(Key words: chromium, adipose tissue, metabolic regulation, lactation)

Received December 27, 2004.

Accepted March 2, 2005.

Corresponding author: John P. McNamara; e-mail: mcnamara@ wsu.edu.

*This paper was published with partial support from Kemin Agri Foods North America, Inc., Des Moines, Iowa, and the Agricultural Research Center, Washington State University (Pullman, WA). This paper was published in conjunction with the NC-1009 CREES Regional Research Project "Protein Synthesis in Lactating Dairy Cattle."

\begin{abstract}
Abbreviation key: Both = diet supplemented with calcium propionate and chromium propionate, $\mathbf{C}=$ control diet, $\mathbf{C a P}=$ diet supplemented with calcium propionate, $\mathbf{C r P}=$ diet supplemented with chromium propionate.
\end{abstract}

\section{INTRODUCTION}

The period of late gestation and early lactation is one of metabolic stress for dairy animals. Improvements in ration balancing and delivery have decreased problems and increased production, yet it remains a challenge to increase intake in amounts sufficient to reduce deficits of amino acids and energy. Glucose flux in the animal during this time affects many systems in the mammary gland, viscera, and central nervous system. The effect of glucose lack on adipose tissue lipolysis has detrimental effects on feed intake and can lead to fat accumulation in the liver, perhaps further diminishing gluconeogenic capacity (Drackley, 1999; Overton and Waldron, 2004). Supplying additional sources of absorbed VFA and glucose usually improves overall performance. The supply of gluconeogenic precursors, such as calcium salts of propionic acid, has improved performance in some situations (Hayirli et al., 2000; Overton and Waldron, 2004). Moreover, lack of knowledge on control of glucose use and interaction among critical organs hampers development of more precise nutritional models (McNamara, 2004).

Chromium is an essential trace element for humans (Anderson, 1992) and laboratory animals (NRC, 1997) for glucose transport into insulin-sensitive cells through its interaction with low molecular weight chromium binding protein (recently suggested to be named chromodulin) (Davis and Vincent, 1997; Vincent, 2004). In recent years, supplemental $\mathrm{Cr}$ in dairy diets (as picolinate or methionine salts) has provided mixed results. Supplemental $\mathrm{Cr}$ has increased milk production in primiparous but not in multiparous cows (Yang et al., 1996). Besong et al. (1996) observed increased milk yield in the first 60 $\mathrm{d}$ of lactation in cows supplemented with $\mathrm{Cr}$ picolinate. Popovic et al. (2000) fed 2 groups of 6 first-lactation animals $4 \mathrm{mg} / \mathrm{d}$ of an organic $\mathrm{Cr}$, and observed a higher average daily milk yield and higher values for milk fat, protein, and lactose. Jackson et al. (1993) reported no 
positive effect on feed intake or milk yield during the first 8 wk of lactation when supplemented with $\mathrm{Cr}$ picolinate. Hayirli et al. (2000) reported altered production responses with $\mathrm{Cr}$ methionine supplementation; milk increased in a quadratic manner being the highest at 0.06 $\mathrm{mg} / \mathrm{kg} \mathrm{BW} \mathrm{BW}^{0.75}$, then dropping below basal levels at 0.12 $\mathrm{mg}$ of Cr-Met $/ \mathrm{kg} \mathrm{BW}{ }^{0.75}$. Recently, Smith et al. (2005) found that chromium methionine at 0.03 or $0.06 \mathrm{mg}$ of $\mathrm{Cr} / \mathrm{kg} \mathrm{BW}^{0.75}$ increased DMI and milk yield in early lactation.

It is not yet clear how supplemental $\mathrm{Cr}$ may increase milk yield in early lactation. A reduction in the rate of mobilization of fatty acids from adipose tissue may allow a greater increase in feed intake, stabilize hepatic fat metabolism, and reduce hepatic ketogenesis, all working to increase milk production. If chromium is acting through glucose transporters in the adipose tissue, this speculation becomes a viable hypothesis. In the study of Besong et al. (1996), increased milk yield with $\mathrm{Cr}$ supplementation was accompanied by increased feed intake; however, feed intake was not affected by supplemental $\mathrm{Cr}$ in the study of Yang et al. (1996). Hayirli et al. (2000) observed an increase in DMI (as a percentage of BW) as lactation progressed, and the recent study of Smith et al. (2005) demonstrated an increase in DMI. It is likely that gluconeogenic precursors (such as calcium propionate) and chromium are acting via different mechanisms to elicit the same effect. The present study was done to investigate the effect on adipose tissue lipogenesis and lipolysis, as well as production effects, of feeding chromium propionate to supply $10 \mathrm{mg}$ of $\mathrm{Cr} / \mathrm{d}$ and calcium propionate to supply $125 \mathrm{~g}$ of propionate/d to highproducing dairy cattle in late pregnancy and early lactation.

\section{MATERIALS AND METHODS}

\section{Experimental Design, Animals, and Diets}

Forty-eight Holstein dairy cows were blocked by parity (second or third and greater), sorted by previous milk production, and allotted within parity and previous production to 1 of 4 treatments (12 animals each). Previous production averaged 10,623 kg + 223 (SEM) milk per 305 $\mathrm{d}$ at $3.62 \%$ fat and $3.21 \%$ true protein, with no difference among treatment allotments. Animals entered the experimental lot (free stall) $28 \mathrm{~d}$ prepartum and were adapted to Calan gates. Treatments began at $21 \mathrm{~d}$ prepartum. Dry period diets were: control [C; $24 \%$ alfalfa silage, $60 \%$ grass hay, and $16 \%$ concentrate (Table 1)]; control plus $0.125 \mathrm{~kg} / \mathrm{d}$ of calcium propionate $(\mathbf{C a P} ; \mathrm{Nu}-$ troCAL; Kemin Agri Foods North America, Inc., Des Moines, IA); control plus chromium propionate (CrP; KemTRACE Cr, Kemin Agri Foods) to supply $10 \mathrm{mg} / \mathrm{d}$ of chromium; and a combination of $\mathrm{CaP}$ and $\mathrm{CrP}$ at the
Table 1. Dietary ingredients and composition of feeds fed to dairy cattle in late pregnancy and early lactation.

\begin{tabular}{|c|c|c|}
\hline Ingredients, \% DM & Dry & Lactation \\
\hline \multicolumn{3}{|l|}{ Ration composition } \\
\hline Alfalfa haylage & 24 & 25.6 \\
\hline Alfalfa hay & & 23.9 \\
\hline Grass hay & 60 & \\
\hline Whole cottonseed & $\ldots$ & 10.4 \\
\hline Wheat mill run & & 7.1 \\
\hline Concentrate & 16 & 33 \\
\hline \multicolumn{3}{|l|}{ Concentrate composition } \\
\hline Corn grain, ground & & 10.6 \\
\hline Barley & 13 & 5.7 \\
\hline Wheat & $\ldots$ & 6.3 \\
\hline Peas & $\ldots$ & 5 \\
\hline Soybean meal & 2.0 & 1.5 \\
\hline Corn gluten meal & & 1.5 \\
\hline Molasses, cane & 0.6 & 0.67 \\
\hline Limestone & $\ldots$ & 0.5 \\
\hline Salt w/selenium & $\ldots$ & 0.5 \\
\hline BiCarb & $\ldots$ & 0.67 \\
\hline Vitamin, mineral, binder (with $\mathrm{MgO})^{1}$ & 0.4 & 0.24 \\
\hline Chromium, mg/kg of grain (control diet) & 1.41 & 2.7 \\
\hline $\begin{array}{l}\text { Chromium, mg/kg of grain } \\
\text { (chromium propionate diet) }\end{array}$ & 6.04 & 3.9 \\
\hline \multicolumn{3}{|l|}{ Chemical composition $^{2}$} \\
\hline DM, \% & 64 & 75 \\
\hline $\mathrm{CP}, \%$ of $\mathrm{DM}$ & 11 & 18 \\
\hline RUP, \% of CP & 34 & 25 \\
\hline $\mathrm{NDF}, \%$ of DM & 49 & 32 \\
\hline $\mathrm{ADF}, \%$ of $\mathrm{DM}$ & 36 & 25 \\
\hline Ash, \% of DM & 12 & 10 \\
\hline $\mathrm{NE}_{\mathrm{L}}, \mathrm{Mcal} / \mathrm{kg}$ of $\mathrm{DM}$ & 1.34 & 1.69 \\
\hline
\end{tabular}

${ }^{1}$ Prepartum rations contained $0.11 \% \mathrm{Cl}, 0.07 \% \mathrm{Na}, 0.033 \mathrm{ppm} \mathrm{Mn}$, $0.007 \mathrm{ppm} \mathrm{Mg}, 0.064 \mathrm{ppm} \mathrm{Zn}, 0.033$ ppm Fe, 0.006 ppm Cu, 0.002 ppm I, $0.002 \mathrm{ppm}$ Se, $0.001 \mathrm{ppm}$ Co, $1.4 \mathrm{IU}$ vitamin A/g, and $1.5 \mathrm{IU}$ vitamin $\mathrm{D} / \mathrm{g}$. The initial postpartum ration contained $0.14 \% \mathrm{Cl}, 0.09 \%$ $\mathrm{Na}, 21.7 \mathrm{ppm} \mathrm{Ca}, 9.1 \mathrm{ppm} \mathrm{Mg}, 2.0 \mathrm{ppm}$ poloxalene (Bloatguard), 0.09 ppm Zn, 0.044 ppm Fe, 0.044 ppm Mn, 0.008 ppm Cu, 0.002 ppm I, $0.002 \mathrm{ppm}$ Se, $0.001 \mathrm{ppm}$ Co, $3.2 \mathrm{IU}$ vitamin $\mathrm{A} / \mathrm{g}$, and $1.9 \mathrm{IU}$ vitamin $\mathrm{D} / \mathrm{g}$. The concentrate was later changed to increase $\mathrm{Zn}, \mathrm{Mn}, \mathrm{Cu}$, and Co concentrations to $0.61,0.34,0.21$, and $0.04 \mathrm{ppm}$.

${ }^{2} \mathrm{All}$ data are analyzed, except for RUP and $\mathrm{NE}_{\mathrm{L}}$, which were calculated from NRC (2001).

same doses as above (Both). Treatments were mixed into the grain portion, which was included in the TMR as a pellet. Lactation diets were alfalfa and alfalfa silagebased and formulated to meet NRC (2001) standards for dry cows and lactating cows and fed as a TMR (Table 1). After calving, animals were switched to the lactation ration, and treatments were continued until 35 DIM, at which time all animals continued on the control diet. During the study (September 2002 through June 2003), some allotted animals were removed from the herd before initiation of treatments due to late abortions or other reasons. Several of these animals could not be suitably replaced, therefore, the final number of animals in the 4 treatment groups (C, CaP, CrP, Both) was 10, 9, 10, and 12. 


\section{Production Data}

Feed offerings, orts, and milk yields were recorded daily. Feed was offered between 0700 and $0800 \mathrm{~h}$, and orts were removed the next day at $0630 \mathrm{~h}$. Milk yield was recorded at each milking (1100 and $2300 \mathrm{~h}$ ) and summarized daily. Milk composition samples were taken (a.m. only) every $2 \mathrm{wk}$ and analyzed at the regional DHIA laboratory in Burlington, WA (Milk-o-Scan, Foss North America, Eden Prairie, MN) using AOAC procedures (AOAC, 1984) for determination of CP, fat, lactose, $\mathrm{SNF}$, and SCC. Feed ingredients were analyzed for DM, $\mathrm{CP}, \mathrm{ADF}, \mathrm{NDF}$, ash, and $\mathrm{Cr}$ by AOAC methods (AOAC, 1984). Body weight and BCS were recorded weekly from $28 \mathrm{~d}$ prepartum to 35 DIM, then biweekly to 84 DIM.

\section{Adipose Tissue Biopsies and Metabolic Flux Measures}

Fat biopsies were removed aseptically from a subset of 6 cows per treatment, from the tailhead region ( 3 to $4 \mathrm{~cm}$ lateral to coccygeal vertebrae in the depression between the ischium and vertebrae) at approximately $\mathrm{d}-7,14,28$, and 56 around parturition as described previously (Smith and McNamara, 1990). The fat tissue was immediately immersed in a bottle containing 200 $\mathrm{mL}$ of warm $\left(37^{\circ} \mathrm{C}\right)$ physiological saline, and sliced (within 15 to $30 \mathrm{~min}$ ) with a calibrated microtome to 500 $\mu \mathrm{m}$ thickness. Slices of approximately 100 to $150 \mathrm{mg}$ were allotted in triplicate to 25-mL Erlenmeyer flasks containing $2 \mathrm{~mL}$ of Krebs-HEPES-buffered medium for determination of lipogenesis and lipolysis. Rates of acetate incorporation into fatty acids and rates of fatty acid release in the basal state, or stimulated with norepinephrine $\left(10^{-5} M\right)$, adenosine deaminase $(6.6 \mathrm{U} / \mathrm{mL})$, and theophylline $(1 \mathrm{mM})$ were determined as described previously (McNamara and Hillers, 1986a,b; McNamara et al., 1995). Data are expressed in rate of flux per gram of tissue per $2 \mathrm{~h}$.

\section{Blood Nutrient Assays}

Blood was collected from the coccygeal vessel of cows at approximately $-14,-7,-4,0,4,7,14,28,56$, and 84 $\mathrm{d}$ around calving. Serum was separated from the samples by centrifugation $(1900 \times g$, $30 \mathrm{~min}$; Sorvall RT6000 $\mathrm{B}$ refrigerated centrifuge, Kendro, Asheville, NC) and frozen at $-20^{\circ} \mathrm{C}$ for later analysis. Glucose was assayed using an enzymatic reaction with hexokinase, which resulted in the formation of glucose-6-phospate, followed by a reaction with glucose-6-phosphate dehydrogenase to form NADPH, which was then reacted with a dye (phenazine methosulfate) that then reduced iodonitrotetrazolium chloride, which was measured colorimetrically at $520 \mathrm{~nm}$, following a reaction recipe supplied by Sigma (procedure no. 115, Sigma Chemical Co., St. Louis, MO; Kunsst et al., 1984). Nonesterified fatty acids were assayed enzymatically using acyl CoA synthetase and acyl CoA oxidase to produce hydrogen peroxide that reacted with a dye to form a reactant absorbing at $550 \mathrm{~nm}$ (Wako, \#994-75409E, Wako, Neuss, Germany; modified by McNamara and Hillers, 1986a,b).

\section{Statistical Analyses}

The experiment was analyzed as a completely random design of 4 treatments with repeated measures. Body weight, BCS, glucose, NEFA, and measures of lipogenesis and lipolysis were analyzed using the following model:

$$
\begin{aligned}
\mathrm{Y}_{\mathrm{ijkl}}= & \left.\mathrm{u}+\mathrm{T}_{\mathrm{i}}+\operatorname{Cow}(\mathrm{T})_{\mathrm{j}} \text { [main plot error }\right]+\mathrm{Day}_{\mathrm{k}} \\
& +\mathrm{T} \times \text { Day }_{\mathrm{ikj}}+\text { error }_{\mathrm{ijkl}}[\text { subplot error }]
\end{aligned}
$$

where $u$ is the sample mean; $T_{i}$ is the mean of the ith treatment; $\operatorname{Cow}(\mathrm{T})_{\mathrm{j}}$ is the mean of cow within treatment; Day $_{\mathrm{k}}$ is mean of kth day; $\mathrm{T} \times \mathrm{Day}_{\mathrm{ijk}}$ is treatment $\times$ day interaction; and error $\mathrm{ijkl}_{\mathrm{jk}}$ is the subplot error.

Statistical significance between treatment means was determined using the PROC MIXED protocol (SAS Institute, 1999). Milk production and DMI were analyzed with a model as above, with Day being a continuous variable for day before and after calving. Feed intake and milk production were also summarized for the 5 periods: prepartum, 1 to 35 DIM, 36 to 56 DIM, 57 to $90 \mathrm{DIM}$, and 1 to $90 \mathrm{DIM}$, and were analyzed again with this model:

$$
\mathrm{Y}_{\mathrm{ij}}=\mathrm{u}+\mathrm{T}_{\mathrm{i}}+\text { error }_{\mathrm{ij}}
$$

where $\mathrm{T}_{\mathrm{i}}$ was the treatment effect and error: cow within treatment. Contrast comparisons were also conducted for control vs. each treatment (separately) and the $\mathrm{CaP}$ and $\mathrm{CrP}$ treatments vs. Both. Statistical significance between treatment means for these variables was determined using the PROC MIXED protocol (SAS Institute, 1999).

\section{RESULTS AND DISCUSSION}

\section{Intake and Milk Production Variables}

Concentrations of chromium in the control grain concentrate were approximately 1.4 and $2.7 \mathrm{mg} / \mathrm{kg}$ for dry and lactating grain; $\mathrm{CrP}$ treatment increased this to 6.0 and $3.9 \mathrm{mg} / \mathrm{kg}$ (Table 1 ). This provided close to the target amount of $10 \mathrm{mg} / \mathrm{d}$ at the measured intakes (Table 2). Forage samples assayed were below detectable limits for chromium. Analysis of the diets showed that the average 
Table 2. Dry matter and chromium intakes of cows treated with calcium propionate $(\mathrm{CaP})$, chromium propionate $(\mathrm{CrP})$, or both.

\begin{tabular}{|c|c|c|c|c|c|c|c|c|}
\hline \multirow[b]{3}{*}{ Item } & \multirow{2}{*}{\multicolumn{4}{|c|}{ Treatment }} & \multirow[b]{3}{*}{$\mathrm{SE}$} & \multicolumn{3}{|c|}{ Contrasts $^{1}$} \\
\hline & & & & & & $C$ ys & $C$ ys & \\
\hline & Control & $\mathrm{CaP}$ & $\mathrm{CrP}$ & Both & & $\mathrm{CaP}$ & $\mathrm{CrP}$ & Both \\
\hline \multicolumn{9}{|l|}{ DMI, kg/d } \\
\hline 21 to $1 \mathrm{~d}$ prepartum & 10.6 & 11.8 & 11.4 & 10.3 & 0.45 & 0.12 & NS & NS \\
\hline 1 to $35 \mathrm{DIM}$ & 17.0 & 18.8 & 18.7 & 15.1 & 0.82 & NS & NS & NS \\
\hline 36 to $56 \mathrm{DIM}$ & 21.8 & 24.7 & 25.9 & 21.0 & 0.90 & 0.05 & 0.01 & NS \\
\hline 57 to $90 \mathrm{DIM}$ & 22.2 & 25.6 & 26.6 & 23.2 & 0.88 & 0.03 & 0.003 & NS \\
\hline 1 to $90 \mathrm{DIM}$ & 20.0 & 22.7 & 23.1 & 19.5 & 0.70 & 0.03 & 0.005 & NS \\
\hline \multicolumn{9}{|l|}{ Chromium intake, $\mathrm{mg} / \mathrm{d}$} \\
\hline 21 to $1 \mathrm{~d}$ prepartum & 2.4 & 2.7 & 11.0 & 9.9 & & & & \\
\hline 1 to $35 \mathrm{DIM}$ & 15.2 & 16.8 & 24.3 & 19.4 & & & & \\
\hline No. of animals & 10 & 9 & 10 & 12 & & & & \\
\hline
\end{tabular}

${ }^{1}$ Contrasts were control vs. calcium propionate; control vs. chromium propionate; and control vs. both.

additional intake of $\mathrm{Cr}$ in the dry period was about 8 $\mathrm{mg} / \mathrm{d}$; whereas in the lactating period, it was just under $10 \mathrm{mg} / \mathrm{d}$. Control lactating grain contained more $\mathrm{Cr}$ than the dry period grain, apparently from the corn, wheat, or peas. It would be prudent to determine more detail on chromium concentrations in feedstuffs than is presently available.

Treating cows with $\mathrm{CaP}$ tended to increase DMI over the entire period (Figure 1). Before calving, this was a trend $(P=0.13$; Table 2$)$. Dry matter intake increased after calving $(P<0.05)$ in CaP treated cows (Figure 1 , Table 2). Mean DMI of the CrP treatment group was 0.8 $\mathrm{kg} / \mathrm{d}$ greater before calving than the $\mathrm{C}$ group; this was not statistically significant (Table 2). Chromium propionate increased feed intake after calving compared with the control group by $3.1 \mathrm{~kg} / \mathrm{d}(P<0.005$; Figure 1 , Table 2$)$.

There was a DIM by treatment interaction for milk yield in the CrP group $(P<0.05 ;$ Figure 2$)$. The summary

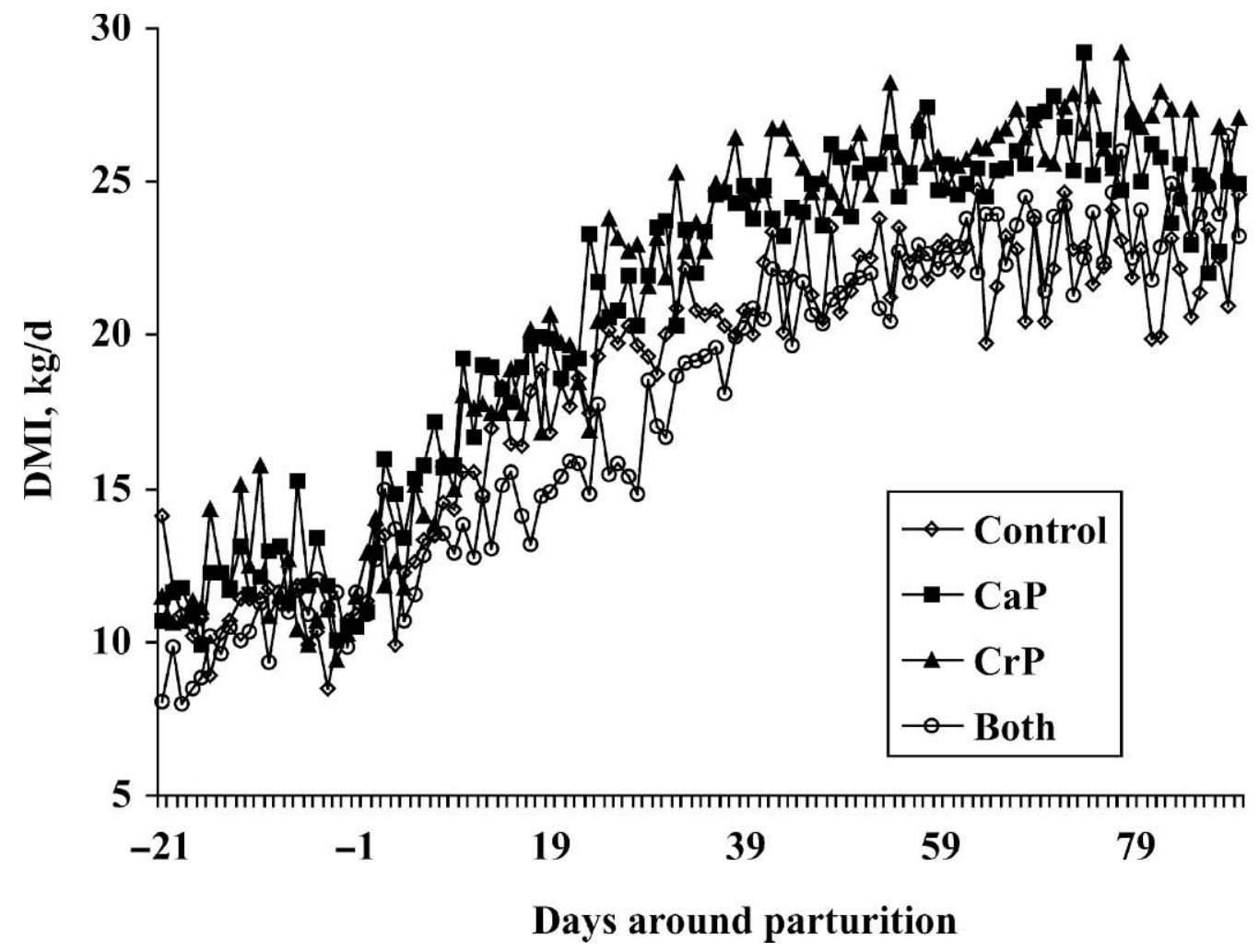

Figure 1. Dry matter intake of Holstein cattle in late pregnancy and early lactation fed calcium propionate $(\mathrm{CaP} ; 0.25 \mathrm{~kg} / \mathrm{d})$, chromium propionate $(\mathrm{CrP} ; 10 \mathrm{mg}$ of $\mathrm{Cr} / \mathrm{d})$, or both. The $\mathrm{CaP}$ and $\mathrm{CrP}$ treatments were different from control $(P<0.05)$ and there was a treatment by day interaction $(P<0.001)$. 


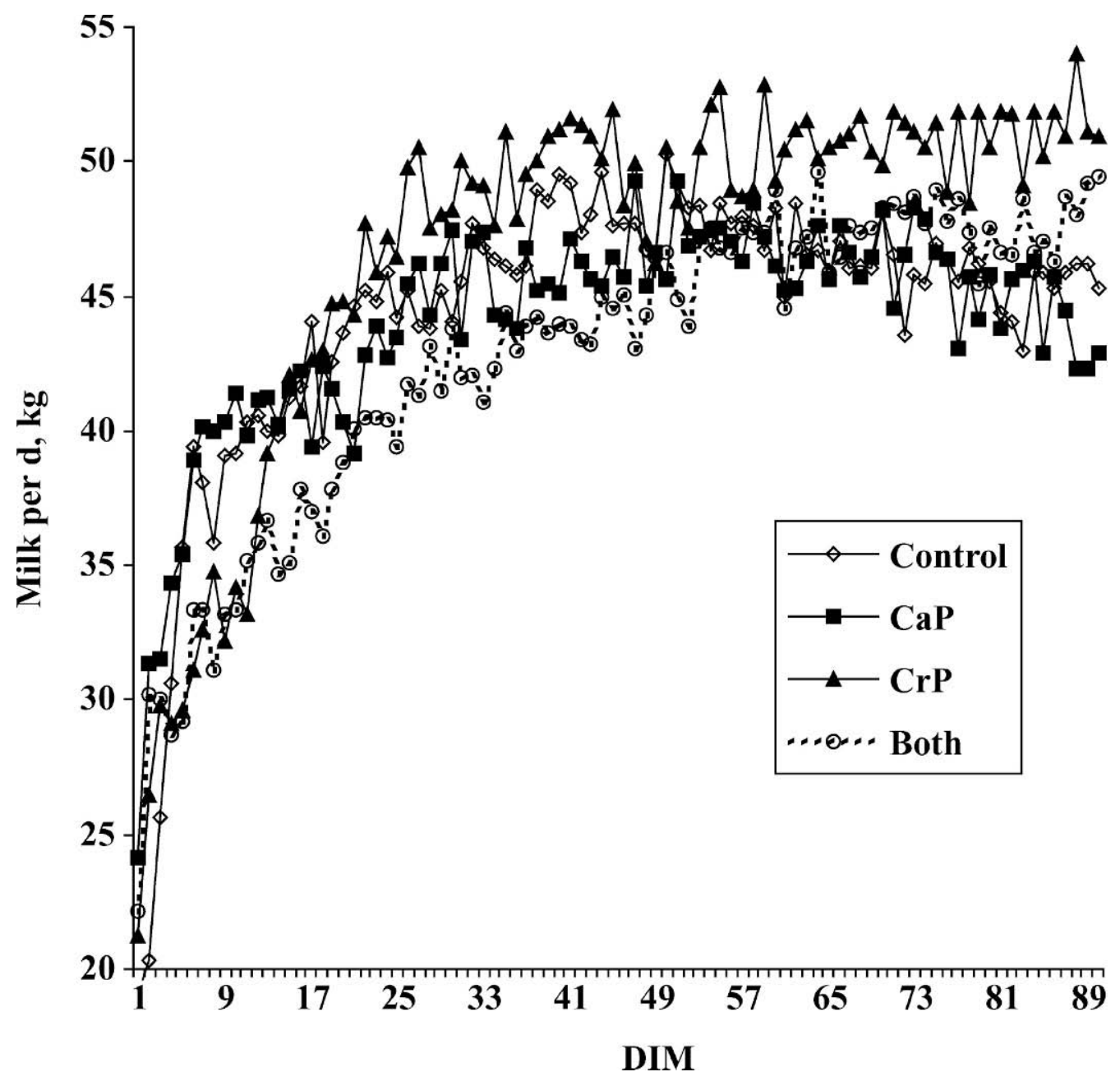

Figure 2. Milk production of Holstein cattle in late pregnancy and early lactation fed calcium propionate $(\mathrm{CaP} ; 0.25 \mathrm{~kg} / \mathrm{d})$, chromium propionate $(\mathrm{CrP} ; 10 \mathrm{mg}$ of $\mathrm{Cr} / \mathrm{d})$, or both. The $\mathrm{CaP}$ and $\mathrm{CrP}$ treatments were different from control $(P<0.05)$ and there was a treatment by day interaction $(P<0.001)$.

(mean) analysis showed that milk yield was $2.6 \mathrm{~kg} / \mathrm{d}$ greater due to $\mathrm{CrP}$ from $\mathrm{d} 1$ to $90(P=0.13$ for various periods (Figure 2, Table 3). For d 57 to 90 , this was 4.6 $\mathrm{kg} / \mathrm{d}$ greater. The apparent lag in response in milk yield compared with feed intake suggests that the feed intake effect came first.

In the treatment group that combined both propionate salts, 5 of 12 cows developed displaced abomasums. The

Table 3. Milk production from cows treated with calcium propionate $(\mathrm{CaP})$, calcium propionate $(\mathrm{CrP})$, or both.

\begin{tabular}{|c|c|c|c|c|c|c|c|c|}
\hline \multirow[b]{3}{*}{ Item } & \multirow{2}{*}{\multicolumn{4}{|c|}{ Treatment }} & \multirow[b]{3}{*}{ SE } & \multicolumn{3}{|c|}{ Contrasts $^{1}$} \\
\hline & & & & & & C vs. & C vs. & C vs. \\
\hline & Control & $\mathrm{CaP}$ & $\mathrm{CrP}$ & Both & & $\mathrm{CaP}$ & $\mathrm{CrP}$ & Both \\
\hline \multicolumn{9}{|l|}{ Milk, kg/d } \\
\hline 1 to 35 DIM & 40.8 & 40.7 & 41.6 & 37.2 & 0.91 & NS & NS & 0.09 \\
\hline 36 to 56 DIM & 47.4 & 44.7 & 49.9 & 44.5 & 0.99 & NS & NS & NS \\
\hline 57 to $90 \mathrm{DIM}$ & 45.4 & 45.8 & 50.0 & 47.2 & 1.03 & NS & 0.13 & NS \\
\hline 1 to 90 DIM & 44.2 & 43.7 & 46.8 & 42.6 & 0.87 & NS & 0.13 & NS \\
\hline No. of animals & 10 & 9 & 10 & 12 & & & & \\
\hline
\end{tabular}

\footnotetext{
${ }^{1}$ Contrasts were control vs. calcium propionate; control vs. chromium propionate; and control vs. both.
} 
mean for this treatment of all 12 animals was not statistically different from control in either DMI or milk yield, although mean DMI for the first $35 \mathrm{~d}$ was about $2 \mathrm{~kg} / \mathrm{d}$ less than control. Removing the animals with displaced abomasum from the analysis slightly improved DMI and milk yield, but did not change statistical inferences. There is no clear reason from previous knowledge on calcium, chromium, or propionate metabolism that would explain such an increase in displaced abomasums. Total $\mathrm{Ca}$ and total propionate levels in the combined treatment were the same as with the $\mathrm{CaP}$ treatment, as $\mathrm{CrP}$ was fed to supply $10 \mathrm{mg}$ of $\mathrm{Cr}$ and thus supplied only about $30 \mathrm{mg}$ of additional propionate/d. Our working inference is that the displaced abomasums and resultant loss of treatment response occurred by chance.

Content of milk lactose, protein, other solids, and SCC did not vary with treatment (Table 4). Milk fat percentage and yield were lower in the $\mathrm{CaP}$ and $\mathrm{CrP}$ treatment groups by 0.16 and 0.27 percentage units and 130 and $70 \mathrm{~g} / \mathrm{d}$ compared with controls; statistically these effects were trends (CrP: $P=0.06$; CaP: $P=0.11$ ).

\section{BW, BCS, and Blood Metabolites}

Body weights and BCS behaved as expected for transition cows, and there were no effects of treatment on animal BW or BCS (Figure 3). The same was true for serum glucose and NEFA (no effects, Figure 4), although the animals in the Both treatment group had a slightly (numerically) higher NEFA, consistent with the lower feed intake. There is no compelling reason to think that these treatments would cause changes in BW or BCS over this period, especially if milk production was increased. There is also no convincing reason to expect a large change in serum glucose due to treatment, as any additional glucose used could be derived from amino acids.

\section{Adipose Tissue Metabolism}

Feeding propionate salts may have benefit by merit of being a precursor to glucose. This may allow for an increase in milk production and feed intake. The most plausible theory, based on a large amount of data in cattle and other species, is that glucose would reduce the fatty acids mobilized from adipose tissue, and that increased circulating fatty acids tend to inhibit feeding behavior through central nervous system control (Hayirli et al., 2002; Overton and Waldron, 2004, and references therein). Chromium functions as part of a low molecular weight chromium binding protein (recently named chromodulin), which is linked to the action of the insulin receptor (Vincent, 2004). If an animal has an inadequate amount of chromium, an additional amount of chromium may increase glucose use by insulin-dependent organs such as muscle and adipose tissue. This has been demonstrated in young pigs, rodents, and dairy cattle (Anderson, 1992; Amoikon et al., 1995; Petterson, 2000; Van de Ligt et al., 2002; Vincent, 2004). A plausible theory is that the transition dairy cow is in need of increased chromodulin because of the increased metabolic rate and glucose use, thus an increased supply of chromium may increase glucose uptake by these organs. The molecular mechanisms of this system are still not known; however, if such an effect occurs, and glucose entry to adipocytes is increased, lipogenesis from acetate will increase and could decrease net fatty acid release from the cell.

In this study, addition of either $\mathrm{CaP}$ or $\mathrm{CrP}$ did not increase rates of lipogenesis prepartum, when the cows were in positive energy balance and rates were already high (Figure 5). After calving, all cows had a large and expected (McNamara and Hillers, 1986a; McNamara, 2004) drop in lipogenesis. However, rates in $\mathrm{CaP}-$ and CrP-treated cows were much greater than in control cows at 14, 28, and $56 \mathrm{~d}$ postpartum. At 56 DIM, when control cows had not yet begun their normal rebound in adipose tissue lipogenesis, cows treated with $\mathrm{CaP}$ or $\mathrm{CrP}$ were eating more, producing the same or more milk, and showing increased adipose tissue lipogenesis (Figure 5).

The effects on adipose tissue lipolysis rates were more variable but consistent with the feed intake, milk yield and adipose lipogenesis data (Figures 6 and 7). We measured both basal rates and rates stimulated with norepinephrine. Although the exact relationship between in vitro and in vivo rates is always questionable, the body of knowledge for dairy cattle (McNamara 2003; 2004) and analysis with mechanistic models compared with energy and fat input/output data (McNamara, 2003, 2004; McNamara and Baldwin, 2000) suggest that the rates in vivo are much closer to the rates measured under in vitro stimulation than to basal rates. This is in keeping with the known chronic stimulation of lipolysis from the sympathetic nervous system in vitro (McNamara and Murray, 2001). In any case, the effects of treatment on basal and stimulated rates were similar in nature.

Prepartum, there were decreases in basal and stimulated rates of lipolysis at 14 DIM (Figures 6 and 7). This has not been observed before; previous work in our laboratory and others has shown the opposite (McNamara, 2004). These cattle were eating more food overall than cattle in our previous trials; thus, they may not have had to draw as much on adipose lipid. There was no difference among treatments at 14 DIM, whereas at 28 DIM, CaP and CrP treatments had only 60 to $70 \%$ as fast lipolysis as controls. At 56 DIM, basal rates increased in CaP-treated cows, and stimulated rates of lipolysis increased in both treatment groups, which may 
Table 4. Milk composition of cows treated with calcium propionate $(\mathrm{CaP})$, chromium propionate $(\mathrm{CrP})$, or both.

\begin{tabular}{|c|c|c|c|c|}
\hline \multirow[b]{2}{*}{ Item $^{1}$} & \multicolumn{4}{|c|}{ Treatment } \\
\hline & Control & $\mathrm{CaP}$ & $\mathrm{CrP}$ & Both \\
\hline \multicolumn{5}{|l|}{ Milk fat, $\%$} \\
\hline 14 DIM & 4.59 & 4.00 & 3.72 & 4.67 \\
\hline 28 DIM & 3.83 & 3.25 & 3.18 & 3.88 \\
\hline 42 DIM & 3.34 & 3.46 & 3.37 & 3.53 \\
\hline 56 DIM & 3.14 & 2.84 & 3.16 & 3.11 \\
\hline 70 DIM & 3.45 & 3.25 & 3.35 & 3.86 \\
\hline 84 DIM & 3.27 & 3.44 & 2.62 & 3.11 \\
\hline Overall & 3.56 & 3.32 & 3.25 & 3.65 \\
\hline $\begin{array}{l}\text { Average, d } 28 \text { to } \\
\text { d } 84\end{array}$ & 3.41 & 3.24 & 3.14 & 3.50 \\
\hline SE, milk fat $\%$ & \multicolumn{4}{|c|}{0.07} \\
\hline Milk fat, kg/d & 1.59 & 1.46 & 1.52 & 1.56 \\
\hline Protein:fat ratio & 0.83 & 0.92 & 0.88 & 0.79 \\
\hline \multicolumn{5}{|l|}{ Milk protein, $\%$} \\
\hline 14 DIM & 3.35 & 3.28 & 3.03 & 3.08 \\
\hline 28 DIM & 2.95 & 3.03 & 2.9 & 2.92 \\
\hline 42 DIM & 2.86 & 2.97 & 2.78 & 2.82 \\
\hline 56 DIM & 2.88 & 2.97 & 2.86 & 2.91 \\
\hline 70 DIM & 2.90 & 3.06 & 2.81 & 2.82 \\
\hline 84 DIM & 3.01 & 3.01 & 2.82 & 2.85 \\
\hline Overall & 2.97 & 3.04 & 2.87 & 2.89 \\
\hline Protein, kg/d & 1.33 & 1.34 & 1.34 & 1.23 \\
\hline $\mathrm{SE}$, protein \% & \multicolumn{4}{|c|}{0.02} \\
\hline \multicolumn{5}{|l|}{ Lactose, $\%$} \\
\hline 14 DIM & 4.68 & 4.88 & 4.83 & 4.74 \\
\hline 28 DIM & 4.92 & 4.97 & 4.94 & 5.04 \\
\hline 42 DIM & 4.98 & 4.96 & 4.95 & 5.01 \\
\hline 56 DIM & 5.04 & 4.94 & 4.97 & 5.05 \\
\hline 70 DIM & 4.90 & 4.91 & 4.94 & 4.98 \\
\hline 84 DIM & 4.90 & 4.95 & 4.95 & 4.98 \\
\hline Overall & 4.91 & 4.94 & 4.93 & 4.97 \\
\hline Lactose, $\mathrm{kg} / \mathrm{d}$ & 2.20 & 2.17 & 2.31 & 2.12 \\
\hline $\mathrm{SE}$, lactose \% & \multirow{2}{*}{\multicolumn{4}{|c|}{0.014}} \\
\hline SCC & & & & \\
\hline 14 DIM & 226 & 54 & 144 & 64.8 \\
\hline 28 DIM & 142 & 17 & 27.6 & 65.2 \\
\hline 42 DIM & 91 & 183 & 23 & 105 \\
\hline 56 DIM & 19 & 50 & 14.5 & 107 \\
\hline 70 DIM & 89 & 59 & 47.7 & 148 \\
\hline 84 DIM & 50 & 94 & 32.5 & 97.7 \\
\hline Overall & 102.8 & 74.2 & 50.1 & 101 \\
\hline SE, SCC & \multicolumn{4}{|c|}{11.5} \\
\hline
\end{tabular}

${ }^{1}$ Fat effects, DIM $P<0.0007$; CrP $P=0.06$; CaP, $P=0.11$; protein effects: treatment, $P=0.14$; DIM, $P$ $<0.0001$; lactose effects, DIM, $P<0.0001$; SCC effects, treatment, $P<0.05$.

be due to the greater milk production. Coupled with the large increase in lipogenesis in these animals, it is clear that they were able to consume more food, make the same amount of milk, and begin to restore adipose lipid simultaneously. For CrP-treated cows, the rates of lipolysis were almost the same as control cows, whereas lipogenesis and milk production were greater. Thus, these animals were also able to eat more, make more milk, and replenish adipose lipid faster than control cows. None of the means for lipolysis were statistically different, which is not surprising given the large normal variation in this measure, yet the results are certainly consistent within this set of data and in relation to previous known effects of feed intake and milk production (McNamara, 2004).

This is the first study to measure effects of calcium propionate or chromium propionate on adipose tissue metabolism. Effects on milk yield and intake were similar to those measured for chromium methionine by Hayirli et al. (2000) and Smith et al. (2005). Although these data cannot prove direct effects of $\mathrm{CaP}$ and $\mathrm{CrP}$ on glucose entry or on activity of glucose transporters in adipose tissue, the effects are certainly consistent with that theory. Increased lipogenesis with similar or decreased lipolysis would mean a net reduction in free fatty acid release to the blood. This would be consistent with 


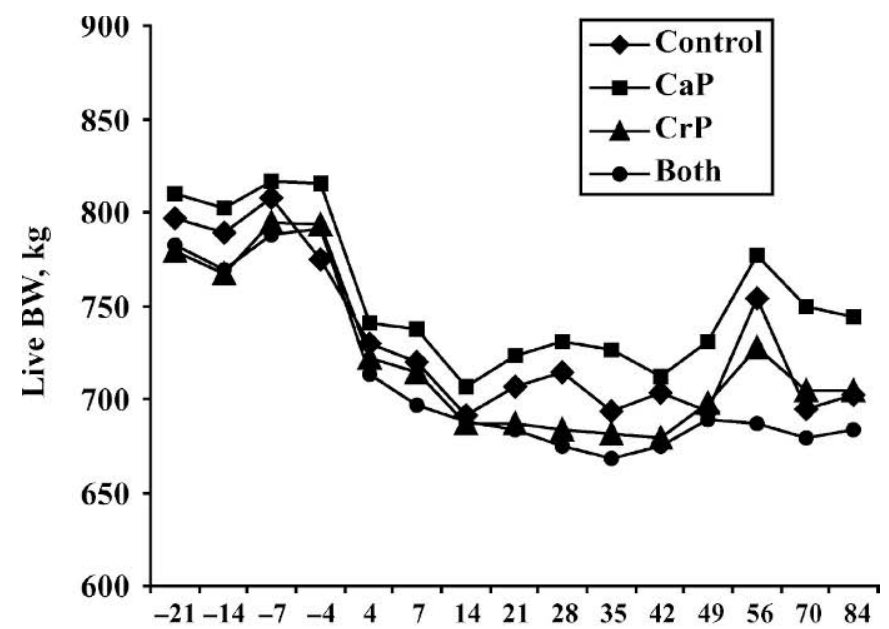

Days around parturition

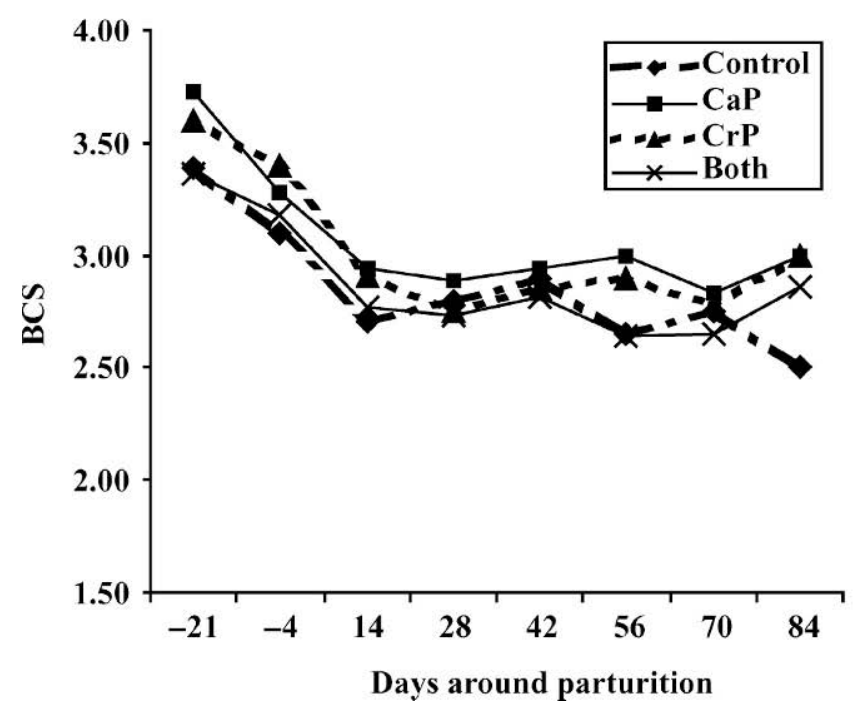

Figure 3. Body weights and BCS of Holstein cattle in late pregnancy and early lactation fed calcium propionate $(\mathrm{CaP} ; 0.25 \mathrm{~kg} / \mathrm{d})$, chromium propionate (CrP; $10 \mathrm{mg}$ of $\mathrm{Cr} / \mathrm{d})$, or both. There were no treatment differences.

allowing a greater increase in feed intake, and therefore, milk production (Drackley, 1999; Overton and Waldron, 2004).

We tested the direct effects of $\mathrm{CaP}$ and $\mathrm{CrP}$ supplied in in vitro incubations on lipogenesis and lipolysis in adipose tissue taken from control and treated cows. We measured no direct effects in vitro (data not shown); however, the incubations were only $2 \mathrm{~h}$ in duration and would not be able to measure effects on increased synthesis of proteins such as chromodulin. In addition, if increased glucose production in the liver (from Ca propionate) provides more glucose to adipose tissue, as is thought, these short-term incubations could not measure that.
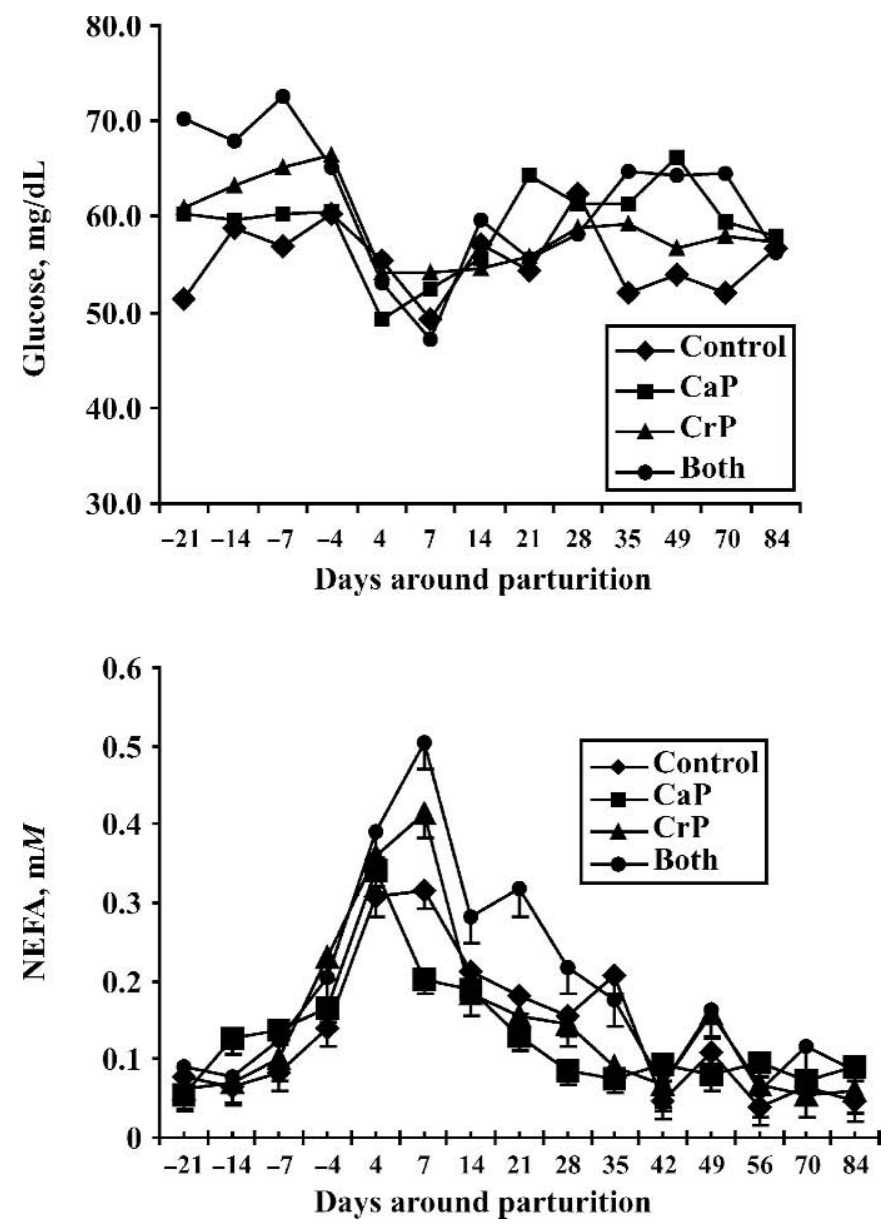

Figure 4. Serum concentrations of glucose $(\mathrm{mg} / \mathrm{dL})$ and nonesterified fatty acids $(\mathrm{m} M)$ in Holstein cattle in late pregnancy and early lactation fed calcium propionate $(\mathrm{CaP} ; 0.25 \mathrm{~kg} / \mathrm{d})$, chromium propionate $(\mathrm{CrP} ; 10 \mathrm{mg}$ of $\mathrm{Cr} / \mathrm{d})$, or both. There were no treatment differences.

The increased supply of glucose from calcium propionate has been demonstrated and may increase glucose supply directly to the mammary gland, but this would not be consistent with the effects in this trial (increase in feed intake but not in milk). It cannot be ruled out that chromium propionate might be having direct effects on the mammary gland. Yang et al. (1996) postulated that increased milk yield might be the result of the indirect effects of $\mathrm{Cr}$ on hepatic glucose production (gluconeogenesis). Conversion of propionate to glucose has increased during intravenous propionate infusion tests in early lactation heifers (Subiyatno et al., 1996) fed supplemental Cr. Bunting et al. (2000) also observed proportional increases in glucose production following propionate infusion in animals given supplemental Cr. Yang et al. (1996) suggested that Cr might promote the activity of IGF receptors, which have structural and functional homology to the insulin receptor. In addition, if chro- 


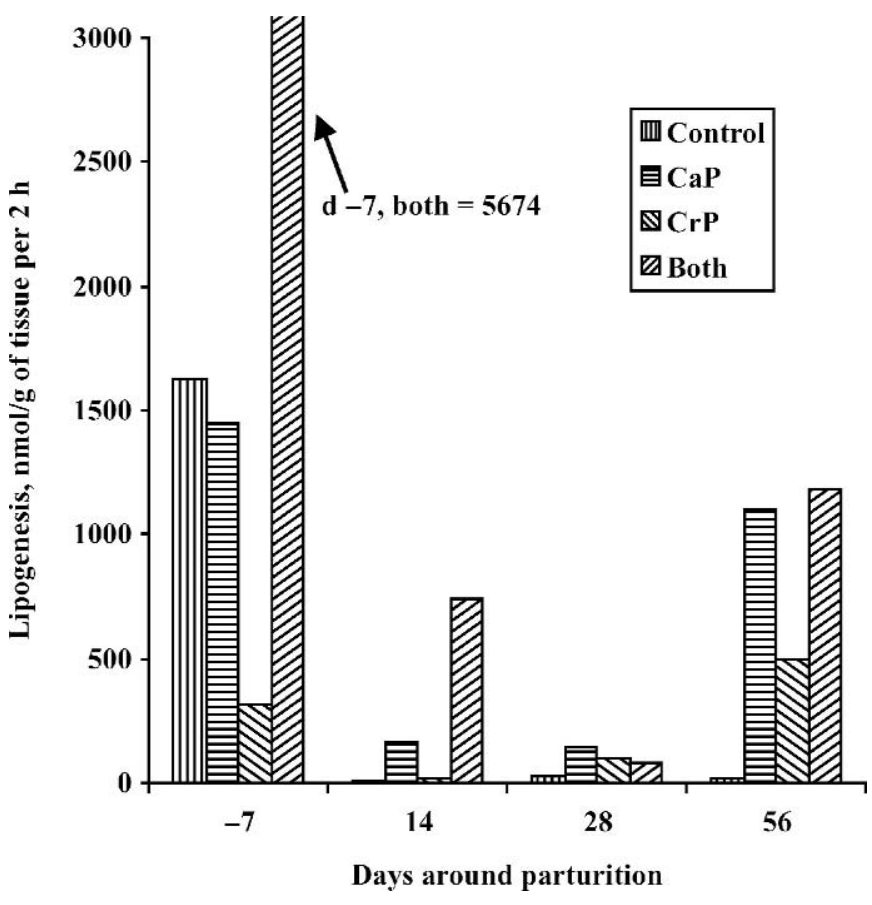

Figure 5. Rates of lipogenesis in adipose tissue in vitro from cattle fed calcium propionate $(\mathrm{CaP})$ or chromium propionate $(\mathrm{CrP})$ from 21 $\mathrm{d}$ prepartum to $35 \mathrm{~d}$ postpartum. There was a treatment effect overall postpartum $(P<0.001)$, and there was a CrP effect by DIM interaction $(P=0.053)$.

mium increases glucose transport into the mammary gland, this would be consistent with the presently observed increase in milk production. Trends for increased circulating IGF-I with $\mathrm{Cr}$ supplementation were observed in the propionate loading tests of Subiyatno et

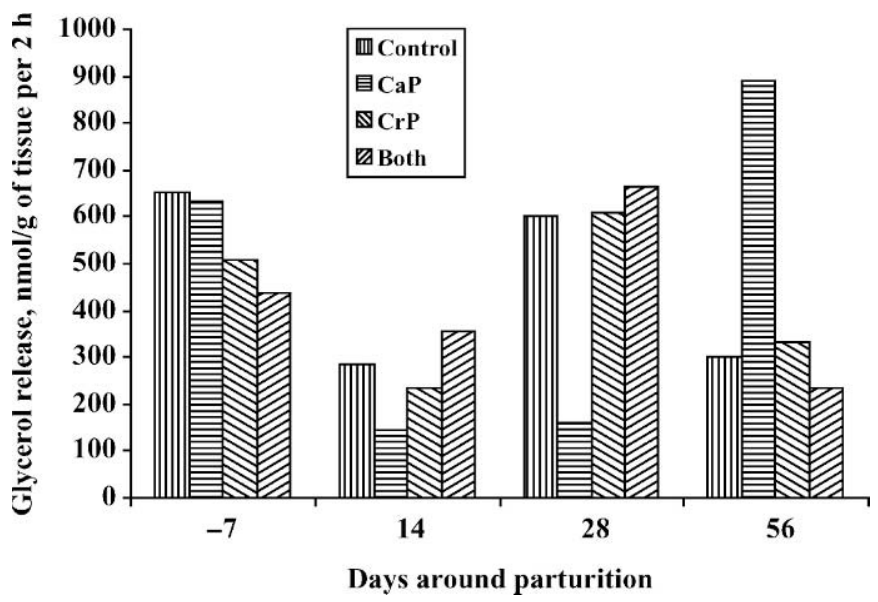

Figure 6. Basal rates of lipolysis in adipose tissue in vitro from dairy cattle fed calcium propionate $(\mathrm{CaP})$ or chromium propionate (CrP) from $21 \mathrm{~d}$ prepartum to $35 \mathrm{~d}$ postpartum. For treatment overall, $P=0.0325$; DIM, $P=0.08$.

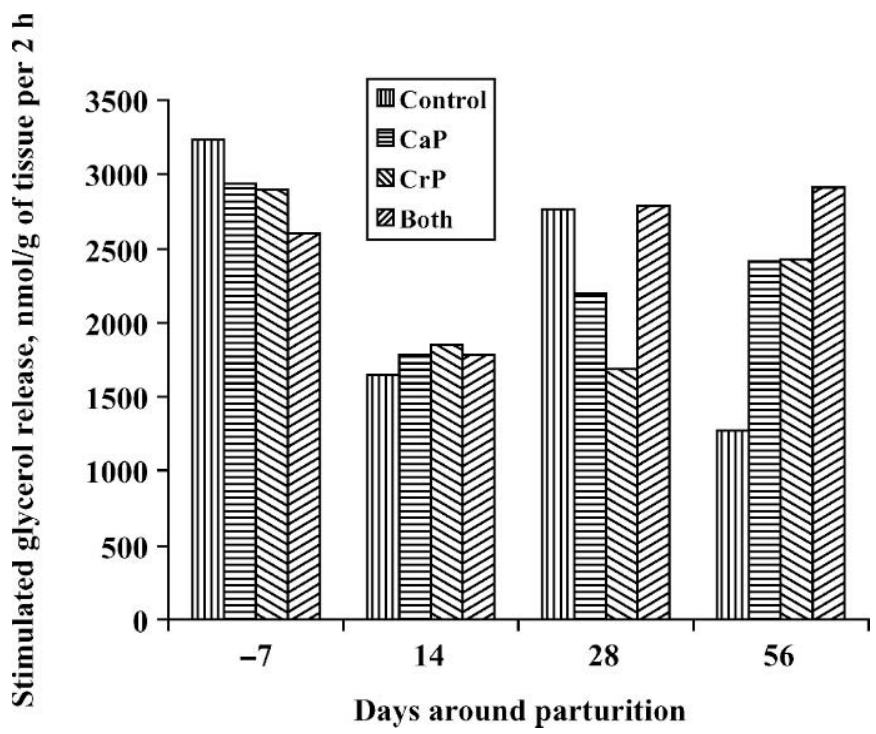

Figure 7. Rates of adipose tissue lipolysis stimulated with norepinephrine from dairy cattle fed calcium propionate $(\mathrm{CaP})$ or chromium propionate $(\mathrm{CrP})$ from $21 \mathrm{~d}$ prepartum to $35 \mathrm{~d}$ postpartum. Effect of norepinephrine stimulation, $P<0.002$.

al. (1996). In work done in growing dairy heifers, we demonstrated a dramatic improvement in glucose clearance rates and increased insulin sensitivity to graded doses of chromium propionate $(5,10,15 \mathrm{mg} / \mathrm{d}$ for $2 \mathrm{wk})(\mathrm{J}$. P. McNamara, J. S. Sumner, and F. Valdez, unpublished results, 2005), suggesting that supplemental chromium does increase glucose entry into adipose and muscle cells.

In this study, there appeared to be a lag in milk yield response to $\mathrm{CrP}$, such that the feed intake effect was obvious even prepartum, but the milk yield effect increased over time $(0.8 \mathrm{~kg} / \mathrm{d}$ for the first $35 \mathrm{~d}$, increasing to $4.6 \mathrm{~kg} / \mathrm{d}$ for d 57 to 90 ). This suggests that $\mathrm{CrP}$ may actually be decreasing net lipolysis, allowing an increased feed intake, reducing the use of body reserves in very early lactation, and then with the continued increase in intake, allowing more substrates for the mammary gland. Nothing in this study argues against that interpretation, although the exact molecular mechanisms of chromium propionate to increase intake and milk production, hasten the recovery of body fat stores, and potential direct effects on the mammary gland remain to be confirmed. The data collected in this study are consistent with the present understanding of metabolism in the cow and the function of chromium in glucose transport.

\section{CONCLUSIONS}

Dairy cattle provided with approximately $10 \mathrm{mg} / \mathrm{d}$ more chromium, as chromium propionate, ate more feed, 
and produced more milk than untreated cows. Cows fed calcium propionate at $0.125 \mathrm{~kg} / \mathrm{d}$ consumed more feed but did not produce as much milk as cows fed additional chromium. Net synthesis of fat in the adipose tissue was increased, and net release was decreased by chromium. This might be acting through linkage of chromodulin with the insulin receptor and glucose transporters. Such an effect of reduced lipolysis would presumably allow a greater rate of intake and thus milk production. Direct action of chromium on glucose uptake by the mammary gland cannot be excluded, but it is not currently thought that the appropriate glucose transporter is active in the bovine mammary gland. Use of both glucogenic precursors such as propionate, or a mineral, chromium, known to increase glucose use by cells, may be of benefit in increasing production of dairy cattle and reducing postpartum problems related to low intake.

\section{ACKNOWLEDGMENTS}

We would like to thank Jan Vierck, Kari Marks, John Swain, and Andrew Minter for their excellent technical assistance.

\section{REFERENCES}

Amoikon, E. K., J. M. Fernandez, L. L. Southern, D. L. Thompson, Jr., T. L. Ward, and B. M. Olcott. 1995. Effect of chromium tripicolinate on growth, glucose tolerance, insulin sensitivity, plasma metabolites, and growth hormone in pigs. J. Anim. Sci. 73:1123-1130.

Anderson, R. A. 1992. Chromium, glucose tolerance, and diabetes. Biol. Trace Elem. Res. 32:19-24.

AOAC. 1984. Official Methods of Analysis. 14th ed. Association of Official Analytical Chemists, Washington, DC.

Besong, S., J. Jackson, S. Trammell, and D. Amaral-Phillips. 1996. Effect of supplemental chromium picolinate on liver triglycerides, blood metabolites, milk yield and milk composition in early lactation cows. J. Dairy Sci. 79(Suppl. 1):196. (Abstr.)

Bunting, L. D., T. A. Tarifa, B. T. Crochet, J. M. Fernandez, C. L. Depew, and J. C. Lovejoy. 2000. Dietary inclusion of chromium propionate and (or) calcium propionate influences gastrointestinal development and insulin function in dairy calves. J. Dairy Sci. 83:2491-2498.

Davis, C. M., and J. B. Vincent. 1997. Chromium oligopeptide activates insulin receptor tyrosine kinase activity. Biochemistry 36:43824385.

Drackley, J. K. 1999. Biology of dairy cows during the transition period: The final frontier. J. Dairy Sci. 82:2259-2273.

Hayirli, A., D. R. Bremmer, S. J. Bertics, M. T. Socha, and R. R. Grummer. 2000. Effect of chromium supplementation on production and metabolic parameters in periparturient dairy cows. J. Dairy Sci. 84:1218-1230.

Hayirli, A., R. R. Grummer, E. V. Nordheim, and P. M. Crump. 2002. Animal and dietary factors affecting feed intake during the prefresh transition period in Holsteins. J. Dairy Sci. 85:3420-3443.
Jackson, J. A., V. Akay, R. Scalette, S. T. Franklin, D. M. AmaralPhillips, C. H. Hamilton, and R. J. Harmon. 1993. Influence of supplemental chromium on performance, concentration of liver triglycerides, and blood metabolites during the transition period of dairy cows. J. Dairy Sci. 76(Suppl. 1):291.

Kunsst, A., B. Draeger, and J. Ziegenhorn. 1984. Pages 163-172 in Methods of enzymatic analysis. Vol. 2. 3rd ed. H. U. Bergmeyer, ed. Academic Press, New York, NY.

McNamara, J. P. 2003. A perspective on research and future of metabolic models of farm animals. Pages 99-112 in Progress in research on energy and protein metabolism. W. B. Souffrant and C. C. Metges, ed. EAAP publication no.109. EAAP, Rome, Italy.

McNamara, J. P. 2004. Research, improvement and application of mechanistic, biochemical, dynamic models of metabolism in lactating dairy cattle. Anim. Feed Sci. Technol. 112:155-176.

McNamara, J. P., and R. L. Baldwin. 2000. Estimation of parameters describing lipid metabolism in lactation: Challenge of existing knowledge described in a model of metabolism. J. Dairy Sci. 83:128-143.

McNamara, J. P., J. H. Harrison, and R. L. Kincaid. 1995. Lipid metabolism in adipose tissue of cows fed high fat rations high in lactation. J. Dairy Sci. 78:2782-2796.

McNamara, J. P., and J. K. Hillers. 1986a. Regulation of bovine adipose tissue metabolism during lactation. 1. Lipid synthesis in response to both increased milk production and decreased energy intake. J. Dairy Sci. 69:3032-3041.

McNamara, J. P., and J. K. Hillers. 1986b. Regulation of bovine adipose tissue metabolism during lactation. 2. Lipolysis response to milk production and energy intake. J. Dairy Sci. 69:3042-3050.

McNamara, J. P., and C. E. Murray. 2001. Sympathetic nervous system activity in adipose tissues during pregnancy and lactation of the rat. J. Dairy Sci. 84:1382-1389.

NRC. 1997. The role of chromium in animal nutrition. National Academy Press, Washington, DC.

Overton, T. R., and M. R. Waldron. 2004. Nutritional management of transition dairy cows: Strategies to optimize metabolic health. J. Dairy Sci. 87(E. Suppl.):E105-E119.

Petterson, S. W. 2000. Effect of chromium on milk production and plasma insulin concentration in dairy cows. Proc. N.Z. Soc. Anim. Prod. 60:307-317.

Popovic, Z. S., A. Veselinovic, N. Ivancev, Z. Ivancev, Z. Cupic, and M. Vukic-Vranjes. 2000. Milk yield in heifers fed rations with chromium supplements during pregnancy. Vet. Glas. 54:39-45.

SAS Institute. 1999. SAS User's Guide: Statistics. SAS Inst., Inc., Cary, NC.

Smith, K. L., M. R. Waldron, J. K. Drackley, M. T. Socha, and T. R. Overton. 2005. Performance of dairy cows as affected by prepartum dietary carbohydrate source and supplementation with chromium throughout the transition period. J. Dairy Sci. 88:255-263.

Smith, T. R., and J. P. McNamara. 1990. Regulation of bovine adipose tissue metabolism during lactation 6 . Cellularity and hormone sensitive lipase activity as affected by genetic merit and energy intake. J. Dairy Sci. 73:772-782.

Subiyatno, A., D. N. Mowat, and W. Z. Yang. 1996. Plasma metabolite responses to glucose infusion in dairy cows supplemented with chelated chromium. J. Dairy Sci. 79:1436-1445.

Van de Ligt, C. P. A., M. D. Lindemann, and G. L. Cromwell. 2002. Assessment of chromium tripicolinate supplementation and dietary protein level on growth, carcass, and blood criteria in growing pigs. J. Anim. Sci. 80:2412-2419.

Vincent, J. B. 2004. Recent advances in the nutritional biochemistry of trivalent chromium. Proc. Nutr. Soc. 63:41-47.

Yang, W. Z., D. N. Mowat, A. Subiyatno, and R. M. Liptrap. 1996. Effects of chromium supplementation on early lactation performance of Holstein cows. Can J. Anim. Sci. 76:221. 